\title{
Landslides Zonation Hazard: relation between geological structures and landslides occurrence in hilly tropical regions of Brazil
}

\author{
RODRIGO I. CERRI ${ }^{1}$, FÁBIO A.G.V. REIS ${ }^{1}$, MARCELO F. GRAMANI ${ }^{2}$, \\ LUCILIA C. GIORDANO ${ }^{1}$ and JOSÉ EDUARDO ZAINE ${ }^{1}$
${ }^{1}$ Universidade Estadual Paulista "Júlio de Mesquita Filho" (UNESP), Instituto de Geociências e Ciências Exatas, Departamento de Geologia Aplicada, Avenida 24A, 1515, Bela Vista, 16506-900 Rio Claro, SP, Brazil
${ }^{2}$ Instituto de Pesquisas Tecnológicas do Estado de São Paulo/IPT, Avenida Prof. Almeida Prado, 532, Cidade Universitária, 05508-901 São Paulo, SP, Brazil

Manuscript received on March 24, 2017; accepted for publication on June 6, 2017

\begin{abstract}
This paper presents a new approach of landslides zonation hazard studies, based on an integrated study of structural data along with geomorphological and external factors, in a hilly regions of Brazil, covered by a tropical humid rain-forest, called Serra do Mar. The Serra do Mar consists of a hilly region along the east coast of Brazil, with high slopes and many geological structures in a gneiss - migmatitic terrain. In contrast to traditional approaches, this method proposes that structural data (foliation, fractures and bedding planes) and its relation with the slope geometry, is important to be consider in the landslide zonation hazard, along with declivity, relative relief, soil and rock properties, land use and vegetation cover and hydrogeological and climate factors. Results show that slopes with high hazard have the same dip direction of geological structures. Landslide zonation hazard using structural data contributes to a better understanding of how these structures, preserved in tropical residual soils, influence on slope stability and generates landslides.
\end{abstract}

Key words: Caraguatatuba, Geological Structures, Landslides, Serra do Mar, Hazard Zonation.

\section{INTRODUCTION}

The studies of shallow landslides in tropical and subtropical rainforest areas consider precipitation dynamics, geomorphological characteristics with special focus on declivity, soil weathering profile, and type/form of anthropic occupation as the main conditioning factors of these processes. Little relevance is given to geological structures as a determining factors for shallow landslides occurrence in these areas, mainly in Brazil.

Correspondence to: Rodrigo Irineu Cerri

E-mail: roocerri@gmail.com
In this context, studies that address the geological structures (foliations, fractures, bedding planes, etc.) as factors that contributes to landslides process are scarce, especially in the context of these processes in Brazilian hilly regions. Silva (2013a), Moura et al. (2012) and Paitan et al. (2014), deal with structural geology and structural determinants (mainly fracture analysis and its relation to slope stability) and their relationships with the probable occurrence of landslides linked to flows influenced by these structures in Brazilian regions.

Anbalagan (1992) and Anbalagan et al. (2008) present the Landslides Zonation Hazard 
method, which encompasses several parameters to determine the landslides potential. These parameters, including geological structures, are traditional conditioning parameters (declivity, altimetry, rock and soil type, soil thickness, land use and vegetation cover, hydrogeological conditions and annual rainfall index) correlating with slope geometry (slope direction, slope value and altimetry) and the geological structures present in the analyzed terrain.

This method presents a new approach, little used in researches developed in tropical highlands areas in Brazil. Landslides studies in the Serra do Mar (e.g., Ramos et al. 2002, Carvalho and Riedel 2005, Lopes et al. 2007), have focused on the declivity parameter in the definition of susceptibility of shallow landslides occurrence, not taking into account the geological structures as conditioning factors and/or controllers of landslides in this region.

In this way, the objective of this paper is to carry out a landslides hazard zonation considering the relationship between the geological structures of the terrain (faults, foliations, fractures, etc.) and the occurrence of landslides locations of these processes in a part of the Serra do Mar mountain range, located at the north coast of São Paulo State, in the Canivetal and Santo Antônio River Basins, northeast of Caraguatatuba city.

The study area presents high potential for the occurrence of landslides and debris flow. The selected river basins are located in the geomorphological domain of Serra do Mar, with high declivity and altimetry, embedded drainage systems and a tropical climate characterized by high precipitation rates. They are among the most affected river basins by landslide events in the region. In addition, it is a strategic area, due to the intense urbanization of the coastal regions, expansion of the industrial sector and implementation of new highways. A accident occurred in Caraguatatuba city, in 1967, with hundreds of landslides and debris flow occurring in the main drainages of the region, and generating significant social, economic and environmental damages, with a great number of human losses (Cruz 1974, 1975, IPT 1987, 1988, 1991, Cerri and Almeida 1990, Nakazawa and Cerri 1990, Ogura and Augusto Filho 1991, Gramani 2001).

The selected river basins are also of an important relevance to the southeast coast of Brazil, since Tamoios and Rio-Santos highways (that pass through the studied river basins), give access to "São Sebastião" port, one of the main port of oil products handling. This region presents an extensive network of pipelines that transport oil to the Brazilian refineries.

It should be noted that landslides are a source of sediment for flow process. Thus, regions with high susceptibilities to the occurrence of landslides associated with high declivity slopes and with a high altimetric difference may be closely related to higher occurrences of flow process.

\section{GEOLOGICAL AND SITE DESCRIPTION}

The municipality of Caraguatatuba (Figure 1) is located in the southeastern region of Brazil, on the north coast of São Paulo State, between the municipalities of "São Sebastião" (south), "Salesópolis" (west), "Paraibuna" and "Ubatuba"

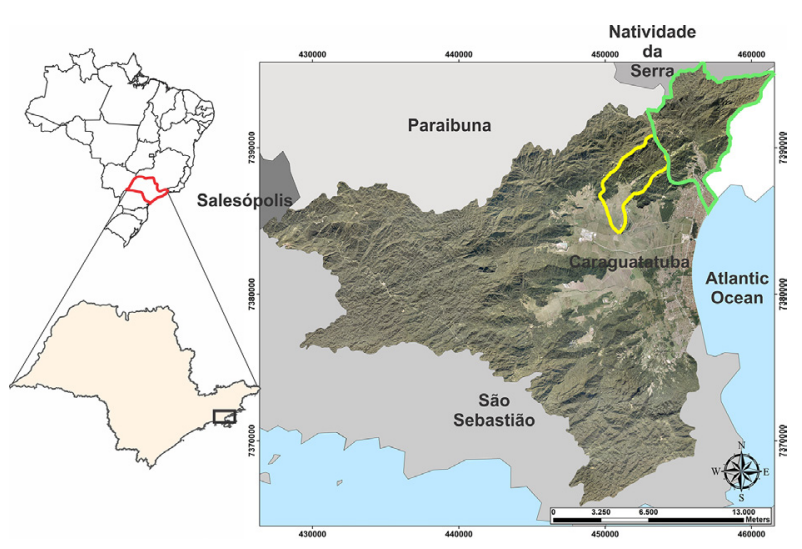

Figure 1 - Location of the study area. The aim of study is located in the yellow (Canivetal River Basin) and green (Santo Antônio River Basin). 
(north). This region has a tourist relevance in Brazil, being intensively occupied in summer months, from December to March, when the population can double or triple.

Caraguatatuba is located in Mantiqueira Orogenic System or Mantiqueira Province, characterized by a Neoproterozoic tectonic process, known as the "Brasiliano" Cycle. This cycle culminated in the collage and amalgamation of the Gondwana Supercontinent. Within the Mantiqueira Province, Caraguatatuba is inserted in the Ribeira Orogenic Belt, occupying the Coastal Complex. This complex comprises mainly peraluminous gneisses rich in garnet and sillimanite, with intercalations of metric quartzite, besides the presence of biotite gneisses, calcium-silicate rocks and amphibolites (Heilbron et al. 2004, Hasui et al. 2012). Thus, they represent the crystalline basement rocks of proterozoic age, including also, foliated granites and cataclastic rocks, associated with shear zones of NE direction, and cut by dikes of the Upper Jurassic and Lower Cretaceous basic and ultrabasic rocks (Hasui et al. 1978, 2012, Chieregati et al. 1982, Campanha et al. 1994, Silva 2013a).

The study area has a strong NE-SW structural orientation that corresponds to the presence of several fault systems and shear zones with same direction, which follow the structural trend of Ribeira Orogenic Belt. According to Hasui et al. (1978), Chieregati et al. (1982) and DNPM/CPRM (1991), the study area also presents the Bertioga - Caraguatatuba and Camburu Faults, as well as other secondary structures such as little faults and dikes with the same direction. The foliations, bandings and migmatitic structures follow the NE and ENE orientation of Ribeira Orogenic Belt. For Caraguatatuba, foliations show preferentially low angle (less than $40^{\circ}$ ) and NE-SW (Campanha et al. 1994).

Geomorphologically, the study area can be characterized by two macro-compartments: Coastal
Province and Atlantic Plateau (Almeida 1964, Ponçano 1981, Chieregati et al. 1982, Ross and Moroz 1997). The municipality of Caraguatatuba presents a complex relief compartmentalization, since it is associated with the presence of escarpments of Serra do Mar, isolated hills and eroded hills in areas near the escarpment border, besides the presence of coastal plain (Silva 2013b). Serra do Mar mountain range in São Paulo State is characterized as a typical plateau border compartment, often leveled at the top at altitudes from 800 to $1200 \mathrm{~m}$ (Vieira and Gramani 2015). Serra do Mar mountain range presents a great variety of geomorphological characteristics (some sections are slopping and continuous, others are irregular and heterogeneous), presenting discontinuous and irregular limits, sometimes arriving near the coast line and others advancing towards the Atlantic Plateau. This variation can be explained by the presence of a complex failure, transcurrent faults and morphotectonic events linked to the genesis of the Atlantic Plateau during the Pleistocene and Miocene (Vieira and Gramani 2015). The main geomorphological characteristics that can be highlighted for the study area are: (i) well-marked presence of landscape dissection; (ii) deep and embedded valleys (usually in geological structures, such as fault and fracture zones); (iii) high drainage density; (iv) steep slopes with angular tops; (v) drainage pattern essentially influenced by geological structures directions (faults, fractures and lithological contacts); (vi) Serra do Mar scarpments, in several points, follow the geological structuring, with preferential direction NE-SW (Ponçano 1981, Ross and Moroz 1997).

Weathered profiles of gneisses, granitegneisses and migmatites (very common in the study area), consist of isalterites. Isalterites are weathered rocks that preserved their petrographic textures, lithologic and tectonic structures (Modenesi and Toledo 1993). The isalterites, according to Modenesi and Toledo (1993), present three main 
constituents: (i) skeleton, characterized by primary minerals of the rock that can be oriented forming foliations or lineation; (ii) plasma, characterized by secondary minerals (clay minerals, oxides and hydroxides); (iii) matrix, formed by the skeleton and the porosity, presenting the conservation of the original organization of the primary minerals, in the form of kaolinite and/or gibbsite pseudomorphous. In this way, tectonic structures of original rock can be preserved in the isalterites, where foliations, fractures, mineral lineations, may be conserved by the growth of secondary minerals (gibbsite and kaolinite) or by the presence of residual primary minerals, such as micas.

Irfan and Woods (1988) point out that in tropical and subtropical regions, rocks are often found to be very disturbed as a result of weathering linked to high temperatures and intense rainfall regimes. Despite this, weathered rocks preserve their discontinuities inherited from the parent rock, playing an important role in the slope stability. The aforementioned authors also consider that preserved discontinuities may contain less resistant materials, acting as preferred paths, which can increase pore pressure and decrease shear strength indices. Soils and residual materials from metamorphic rocks, such as gneisses, schists and migmatites, present anisotropy of shear strength due to the presence of micaceous particles (biotite and muscovite), decreasing the shear strength as these minerals content increases (e.g., Machado Filho 2000, Fonseca et al. 2005, Gobbi et al. 2005). Thus, mica sheets, inherited and orientated according to the structures of the former rock, can generate a more fragile and preferential shear surface, being a fundamental factor for the occurrence of landslides (Souza et al. 2001, Gobbi et al. 2005). Cowland and Carbray (1988) studying slopes with saprolite materials in Hong Kong, conclude that landslides are strongly influenced by preserved discontinuities.

The great majority of landslides in Caraguatatuba occur in cambisols, sometimes associated with latossols that: (i) occur in slope reliefs associated with high declivity, scarps and hilly slopes, intensely moved; (ii) are soils with low developed B horizon, partially evolved, but not enough to change primary minerals such as feldspars and micas; and (iii) have small thicknesses (up to $2 \mathrm{~m}$ ) followed by a saprolite / isalteritic soil, with more than 10 $\mathrm{m}$ thick, and preserved geological structures of the former rock (IPT 2000, Machado Filho 2000, Marcelino 2003).

\section{METHODOLOGY}

The methodological basis of this paper are the research presented by Anbalagan (1992) and Anbalagan et al. (2008), who work with landslide zonation hazard, taking into account the geological structures of the terrain (foliations, fractures, etc.), among other parameters.

This is an empirical method in which slopes are demarcated in zones, varying according to the degree of landslides susceptibility. The method takes into account the causative factors, individual and inherent to the slope instability. We consider eight terrain characteristics, defining ratings for each one, which the aforementioned authors called Landslide Hazard Evaluation Factors (LHEF): (i) lithology (type of rock and its weathered degree); (ii) soil type; (iii) geological structures and their geometric relationship with the slope (angular relationship between geological structure and slope characteristics - direction and dip direction); (iv) slope morphometry (mean declivity); (v) relative relief; (vi) hydrogeological conditions; (vii) land use and land cover types; (viii) annual rainfall index.

The ratings for each of the aforementioned factors can be seen in Tables I, II, III and IV, in which each of the eight terrain characteristics used in the method are described. Thus, each studied slope, divided according to its inclination direction, is characterized with a note. Table $\mathrm{V}$ shows the 
TABLE I

Rating for rock and soil types, and the correction factors for weathering (Anbalagan 1992, Anbalagan et al. 2008).

\begin{tabular}{|c|c|c|c|}
\hline $\begin{array}{l}\text { Causative } \\
\text { Factors }\end{array}$ & Categories & Rating & Observations \\
\hline \multirow{14}{*}{$\begin{array}{l}\text { Lithology } \\
\text { (a) Rock Type }\end{array}$} & Type - I & & \multirow[b]{2}{*}{ Correction factors for weathering: } \\
\hline & Basalt, quartzite and massive limestone and dolomite & 0.2 & \\
\hline & Granite, gabbro and dolerite & 0.3 & \multirow{2}{*}{$\begin{array}{l}\text { (a) Completely weathered: } \\
\text { Rock totally decomposed/ } \\
\text { disintegrated to soil, no or minor } \\
\text { existence of initial rock structure. } \\
\text { Correction Factors } \mathrm{C} 1 \text {; }\end{array}$} \\
\hline & Granite gneiss and metavolcanics & 0.4 & \\
\hline & \multicolumn{2}{|l|}{ Type - II } & \multirow[b]{2}{*}{$\begin{array}{l}\text { (b) Highly weathered: } \\
\text { Rock totally discolored, discontinuity } \\
\text { planes shows weathering products, } \\
\text { rock structure altered heavily with } \\
\text { minor soil formation near surface. } \\
\text { Correction Factors C2. }\end{array}$} \\
\hline & $\begin{array}{l}\text { Well-cemented terrigenous sedimentary rocks } \\
\text { (dominantly sandstones) with minor beds of clay stone } \\
\text { and gneissic rocks }\end{array}$ & 1.0 & \\
\hline & $\begin{array}{l}\text { (dominantly sandstone) with intercalations of clay or } \\
\text { shale beds }\end{array}$ & 1.3 & \multirow{3}{*}{$\begin{array}{l}\text { (c) Moderately weathered: } \\
\text { Rock prominently discolored with } \\
\text { remnant isolated patches of fresh } \\
\text { rock, weathering and alteration } \\
\text { prominent along discontinuity planes, } \\
\text { considerable alteration of rock } \\
\text { structure. } \\
\text { Correction Factors } \mathrm{C} 3 \text {. }\end{array}$} \\
\hline & Type - III & & \\
\hline & Well foliated gneiss & 1.0 & \\
\hline & $\begin{array}{l}\text { Shale, silt, phyllite and other argillaceous rocks like } \\
\text { siltstone, mudstone and claystone }\end{array}$ & 1.2 & Correction Factors $\mathrm{C} 3$. \\
\hline & & & (d) Slightly weathered: \\
\hline & Schistose rocks & 1.4 & $\begin{array}{l}\text { Rock partially discolored along } \\
\text { discontinuity planes indicating }\end{array}$ \\
\hline & $\begin{array}{l}\text { Shale with inter-bedded clayey rocks (siltstone, } \\
\text { mudstone, etc.) }\end{array}$ & 1.8 & $\begin{array}{l}\text { weakening of rock mass, rock } \\
\text { structure is slightly altered. } \\
\text { Correction Factors C4. }\end{array}$ \\
\hline & $\begin{array}{l}\text { Weathered shale and other argillaceous rocks, phyllite } \\
\text { and schistose rocks }\end{array}$ & 2.0 & \\
\hline \multirow{7}{*}{ (b) Soil Type } & Older well compacted fluvial fill material (alluvial) & 0.8 & \multirow{3}{*}{$\begin{array}{l}\text { (e) Faintly weathered: } \\
\text { rock slightly discolored along } \\
\text { discontinuity planes which may be } \\
\text { moderately tight to open in nature, } \\
\text { intact rock structure with or without } \\
\text { minor surface staining. } \\
\text { Correction Factors C5. }\end{array}$} \\
\hline & Clayey soil with naturally formed surface & 1.0 & \\
\hline & Sandy soil with naturally formed surface (alluvial) & 1.4 & \\
\hline & \multicolumn{2}{|l|}{ Debris comprising mostly of rock pieces } & \\
\hline & \multirow{2}{*}{ I. Older well compacted } & \multirow{2}{*}{1.2} & $\begin{array}{l}\text { Correction Factor should be } \\
\text { multiplied by the rating for rock type. }\end{array}$ \\
\hline & & & $\begin{array}{l}\text { Type - I: } C 1=4.0 ; C 2=3.5 \\
C 3=3.0 ; C 4=2.5 ; C 5=2.0\end{array}$ \\
\hline & II. Younger loose material & 2.0 & $\begin{array}{l}\text { Type - II: } C 1=1.5 ; C 2=1.35 \\
C 3=1.25 ; C 4=1.15 ; C 5=1.0 .\end{array}$ \\
\hline
\end{tabular}


TABLE II

Rating for relationship of parallelism between slope and discontinuity (a), amount of dip/plunge of discontinuity and that of slope inclination (b), and ratings for amount of dip of discontinuity (c) (Anbalagan 1992, Anbalagan et al. 2008).

\begin{tabular}{|c|c|c|c|}
\hline Causative Factors & Categories & Rating & Observations \\
\hline Structures & & & \multirow{6}{*}{$\begin{array}{l}\alpha \mathrm{j}=\text { dip direction of discontinuity } \\
\alpha \mathrm{i}=\text { direction of plunge of the line of intersection of two } \\
\text { discontinuity surfaces } \\
\alpha \mathrm{s}=\text { direction of slope inclination } \\
\text { For slopes falling in category I, the rating for structures in } \\
\text { items (b) and (c) will not be applicable and hence a rating } \\
\text { of zero may be awarded. }\end{array}$} \\
\hline \multirow{5}{*}{$\begin{array}{l}\text { (a) Difference in angle of } \\
\text { parallelism. } \\
\text { PLANAR }(\alpha \mathrm{j}-\alpha \mathrm{s}) \\
\text { WEDGE }(\alpha \mathrm{i}-\alpha \mathrm{s})\end{array}$} & I. $>30^{\circ}$ & 0.2 & \\
\hline & II. $21-30^{\circ}$ & 0.25 & \\
\hline & III. 11 - $20^{\circ}$ & 0.3 & \\
\hline & IV. $6-10^{\circ}$ & 0.4 & \\
\hline & $\mathrm{V} .<5^{\circ}$ & 0.5 & \\
\hline \multirow{5}{*}{$\begin{array}{l}\text { (b) Difference in angles } \\
\text { PLANAR }(\beta \mathrm{j}-\beta \mathrm{s}) \\
\text { WEDGE }(\beta \mathrm{i}-\beta \mathrm{s})\end{array}$} & I. $>10^{\circ}$ & 0.3 & \multirow{5}{*}{$\begin{array}{l}\beta \mathrm{j}=\text { dip amount of discontinuity } \\
\beta \mathrm{i}=\text { amount of plunge of line of intersection of two } \\
\text { discontinuity surfaces } \\
\beta \mathrm{s}=\text { amount of slope inclination }\end{array}$} \\
\hline & II. $0-10^{\circ}$ & 0.5 & \\
\hline & III. $0^{\circ}$ & 0.7 & \\
\hline & IV. $0-\left(-10^{\circ}\right)$ & 0.8 & \\
\hline & V. $<-10^{\circ}$ & 1.0 & \\
\hline \multirow{5}{*}{$\begin{array}{l}\text { (c) Dip amount } \\
\text { PLANAR }(\beta \mathrm{j}) \\
\text { WEDGE }(\beta \mathrm{i})\end{array}$} & I. $<15^{\circ}$ & 0.2 & \multirow{5}{*}{$\begin{array}{l}\text { Slope condition: } \\
\text { I. Very favorable } \\
\text { II. Favorable } \\
\text { III. Fair } \\
\text { IV. Unfavorable } \\
\text { V. Very unfavorable }\end{array}$} \\
\hline & II. $16-25^{\circ}$ & 0.25 & \\
\hline & III. $26-35^{\circ}$ & 0.3 & \\
\hline & IV. $36-45^{\circ}$ & 0.4 & \\
\hline & V. $>45^{\circ}$ & 0.5 & \\
\hline
\end{tabular}

TABLE III

Ratings for Slope Morphometry and Relative Relief (Anbalagan 1992, Anbalagan et al. 2008).

\begin{tabular}{cccc}
\hline Causative Factors & Categories & Rating & Observations \\
\hline Morphometry - Slope Type & & & Probable type of failure \\
\hline Escarpment / Cliff & $>65^{\circ}$ & 2.0 & Falls and Topples \\
Very steep slope & $46-65^{\circ}$ & 1.8 & Falls and Topples \\
Steep slope & $36-45^{\circ}$ & 1.6 & Slides \\
Moderately steep slope & $26-35^{\circ}$ & 1.3 & Slides \\
Gentle slope & $16-25^{\circ}$ & 0.8 & Slides with creep movement \\
Very gentle slope & $<15$ & 0.5 & Slides with creep movement \\
Relative Relief Classes & $<50 \mathrm{~m}$ & 0.3 & \\
Very low & $50-100 \mathrm{~m}$ & 0.4 & \\
Low & $101-200 \mathrm{~m}$ & 0.6 & \\
Medium & $201-300 \mathrm{~m}$ & 0.9 & 1.0 \\
Very High & $>300 \mathrm{~m}$ & & \\
\hline
\end{tabular}


TABLE IV

Ratings for Land Use and Land Cover Types, Depth of Soil Cover and Hydrogeological Conditions (Anbalagan 1992, Anbalagan et al. 2008).

\begin{tabular}{|c|c|c|c|}
\hline Causative Factors & Categories & Rating & Observations \\
\hline \multicolumn{4}{|l|}{ Land Use and Land Cover Types } \\
\hline Agricultural land or populated flat land $\left(\leq 15^{\circ}\right)$ & & 0.65 & \\
\hline Thickly vegetated forest area & & 0.8 & \\
\hline Moderately vegetated area & & 1.2 & \\
\hline Sparsely vegetated area with thin grass cover & & 1.5 & \\
\hline Barren land & & 1.8 & \\
\hline $\begin{array}{l}\text { Barren land with slope excavation (cut slopes } \\
\text { for road construction, mining activities, etc) }\end{array}$ & & 2.0 & \\
\hline \multicolumn{4}{|l|}{ Depth of Soil Cover } \\
\hline & $\leq 5 \mathrm{~m}$ & 0.65 & \multirow{5}{*}{$\begin{array}{c}* \text { When depth of soil cover is } \leq 5 \mathrm{~m} \text {, then } \\
\text { put rating of } 1.0 \text { if the slope angle is more } \\
\text { than } 35^{\circ}\end{array}$} \\
\hline & $6-10 m$ & 0.85 & \\
\hline & $11-15 \mathrm{~m}$ & 1.3 & \\
\hline & $16-20 \mathrm{~m}$ & 1.5 & \\
\hline & $>20 \mathrm{~m}$ & 2.0 & \\
\hline \multicolumn{4}{|l|}{ Hydrogeological Conditions } \\
\hline & Flowing & 1.0 & \\
\hline & Dripping & 0.8 & \\
\hline & Wet & 0.5 & \\
\hline & Damp & 0.2 & \\
\hline & Dry & 0 & \\
\hline \multicolumn{4}{|l|}{ Average Annual Rainfall of the area } \\
\hline & $\leq 50 \mathrm{~cm}$ & 0.2 & \\
\hline & $51-100 \mathrm{~cm}$ & 0.3 & \\
\hline & $101-150 \mathrm{~cm}$ & 0.4 & \\
\hline & $\begin{array}{c}>150 \mathrm{~m} \text { or history of } \\
\text { cloud burst }\end{array}$ & 0.5 & \\
\hline
\end{tabular}

TABLE V

Landslides hazard zones based on corrected Total Estimated Hazard (Anbalagan 1992, Anbalagan et al. 2008 ).

\begin{tabular}{ccc}
\hline Hazard Zones & Range of Corrected TEHD value & Description of Zone \\
\hline I & TEHD $<3.5$ & Very Low Hazard \\
II & $3.5 \leq$ TEHD $<5.0$ & Low Hazard \\
III & $5.0 \leq$ TEHD $\leq 6.5$ & Moderate Hazard \\
IV & $6.5<$ TEHD $\leq 8.0$ & High Hazard \\
V & TEHD $>5.0$ & Very High Hazard \\
\hline
\end{tabular}


ranges of note values, which are attributed to a certain degree of susceptibility to the occurrence of landslides, ranging from very low to very high. The final value, called by authors of Total Estimated Hazard (TEHD) (Table V) is the sum of all ratings attributed to the factors presented in Tables I, II, III and IV, generating different degrees of landslides susceptibility.

The basic cartographic materials used were: (i) topographic maps, used to generate declivity and hypsometric maps, as well as for slope delineation considering its slope direction (1:50.000 scale); (ii) geological-structural maps (Chieregati et al. 1982); (iii) and land use and vegetation cover maps, made from orthophotos, with $1 \mathrm{~m}$ resolution). Aerial photos (0.45 $\mathrm{m}$ resolution) and orthophotos were also used to acquire landslides locations of the study area. The division/grouping of the slopes according to their direction of inclination was made using the topographic maps, by structural analyzes, and that takes into account relations between directions and dip of and of the studied slope. From this division, using the ArcGIS 10.1 software, each individual slope had its mean declivity and relative relief measured using ArcGIS 10.1 statistical tools (Zonal Statistics as Table), which allowed the acquisition of specific values of declivity and relative relief for each slope. Each polygon belonging to a specific slope was treated using "Zonal Statistics as Table", obtaining the necessary values to characterize the slopes according to its morphometry, declivity and relative relief.

The landslides susceptibility was calculated and analyzed considering planar and wedges landslides. The parameters set out in Table II were determined using the software "Dips" of Rocscience platform. This software assists in the kinematic analysis of landslides based on structural data obtained in the field, together with the internal friction angle of the analyzed material. The software was used in the case of wedge landslide, to obtain the attitude (direction and dip angle value) of the line of intersection between two discontinuities, which corresponds to a line of the same direction where wedge slip occurs. Thus, in "Dips" analyzes, it is possible to verify which slopes actually presented potentiality for occurrence of wedge or planar landslide.

Fieldwork was carried out aiming: acquisition of structural measurements with "Clar" compass, description of discontinuities, identification of rock type, observations of weathered profiles and identification of landslides evidences. The visited points were within the Canivetal and Santo Antônio River Basins, which are the subject for this landslides hazard zonation.

\section{RESULTS}

Figure 2 shows the study area with slopes separated according to their inclination directions. Altogether, 173 slopes were delimited taking into consideration the parameters of Tables I, II, III and IV. Each slope was analyzed individually, adding the ratings of each parameter, which in the end were summed to obtain the Total Estimated Hazard.

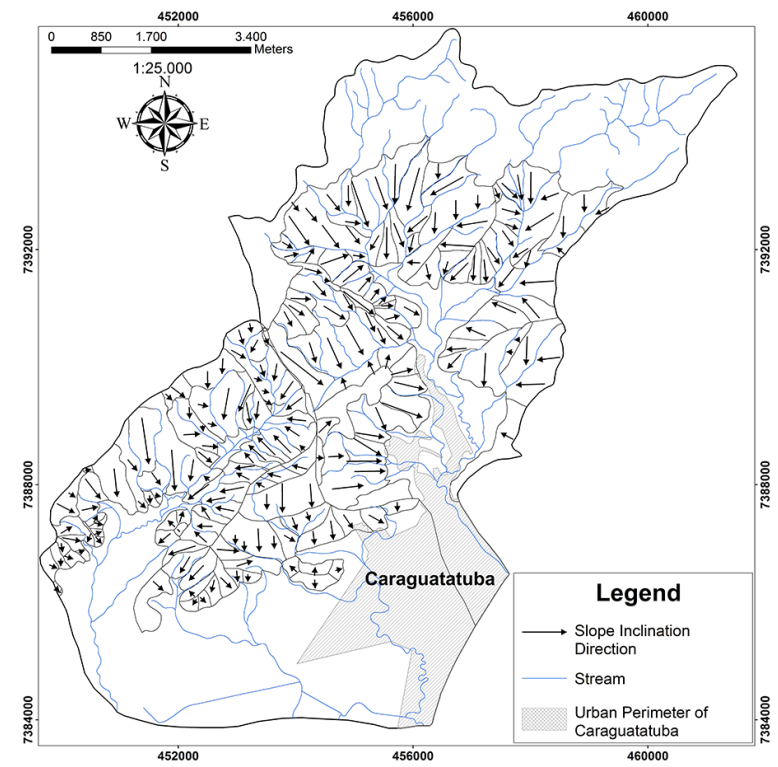

Figure 2 - Northeastern region of Caraguatatuba and the division of slopes according to their inclination directions. 
The lithologies present in the region are basically gneisses, migmatites and gneisses with migmatitic structures, with strong presence of foliations marked by micas (biotite and muscovite) (Figure 3).

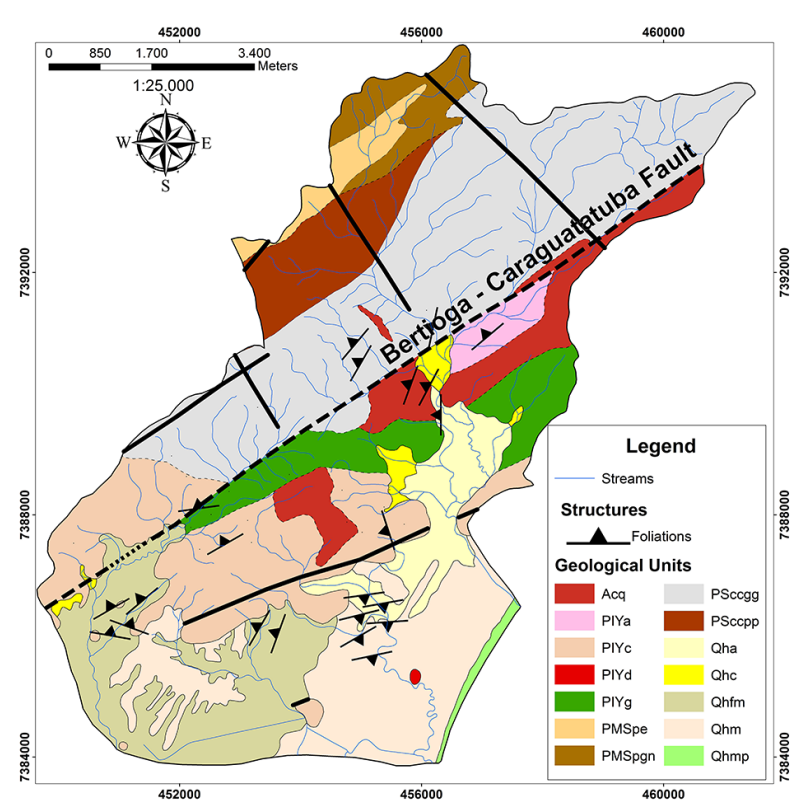

Figure 3 - Geological map of the northeast region of the municipality of Caraguatatuba. The lithologies are: Qha: fluvial sediments; Qhc: coluvial and talus deposits; Qhfm: fluvial - marine sediments; Qhm: marine sediments; Qhmp: beach sediments; Acq: quartzites; PIYa: gneisses and granite-gneiss; PIYc: granite-gneiss; PYId: hornblende-albite-coarse gneiss; PIYg: gneiss and migmatites; PMSpe: mica-schists associated with gneisses; PMSpgn: gneisses; PSccgg: banded gneisses, migmatites and gneisses with migmatite structures; PSccpp: granite-gneiss Pico do Papagaio (Geological-Structural Map compiled from Chieregati et al. (1982) and field data of the authors).

Rock type values (Table I) were predominantly for foliated gneisses (Type - III), not employing the correction factor for weathered rocks. Some regions present rating values smaller than the one used in general, due the presence of quartzites. Since the region is predominantly composed by gneissicmigmatite, with high and intense tectonic influence, the foliated rocks (mostly foliated gneisses) were predominantly used. Granite-gneisses (Type-I) can be observed in some regions, employing the correlation factor $\mathrm{C} 4$, acquiring similar value to the foliated gneisses that predominate in the region.

Through field observation the soil type (Table I) was characterized by a coluvionar soil, young and friable. Most of the soil profiles present little thickness and great structural heterogeneity. Throughout the area, slightly weathered and moderately weathered rock with preservation of geological structures, interspersed with loose materials with large sustained rock blocks. The soil depth (Table IV) is small, not exceeding 2 - $5 \mathrm{~m}$ thick, in agreement with the descriptions of IPT (2000) and Marcelino (2003).

The geological structures were obtained during fieldwork, focusing on structural measure of foliations and bedding planes in rock outcrops and weathered profiles (when geological structures is preserved). These data were plotted on a map together with data taken from the Caraguatatuba Geological Map (Chieregati et al. 1982). The foliations of the area present predominantly NESW direction, dipping to SE and NW, with dip angle values rarely exceeding $40^{\circ}$, agreeing with the observations of Campanha et al. (1994). The fractures present heterogeneous behavior, predominantly vertical with several directions. It is worth mentioning the difficulty in acquiring structural measures in the studied regions, since they present high density of vegetation and few access roads. Measurements were made in regions along drainage and few highways and access roads.

For the structural parameters (Table II), inclination directions and mean declivity of each slope were compared with the geological structures using the "Dips" software, to confirme the probability of landslide occurrence. This parameter is essential to establish a relation between the potentiality of landslide occurrence and the role of geological structures in this scenario. Fault presence (Bertioga - Caraguatatuba Fault) and other smaller fracture zones, strongly influence the structuring of river basins and sub-basins (such as 
the Canivetal River Basin and sub-basins within the Santo Antônio River), which end up acquiring the orientation of these structures, with predominance of NE-SW directions.

The morphometry parameter (Table III) presents great variation along the geological units. The highest slope values (usually above $26^{\circ}$ and rarely exceeding $45^{\circ}$ ) are directly related to regions where there is influence of faults and fracture zones. The Canivetal River Basin presents morphometry varying predominantly between $26-35^{\circ}$ and rarely between $36-45^{\circ}$, with a predominance of slopes with declivities between $16-25^{\circ}$. The Santo Antônio River Basin presents declivities that do not exceed $35^{\circ}$.

Relative relief (Table III) is a parameter that varies independently of the lithologies. In Canivetal River Basin, the great majority of the slopes present amplitudes greater than $300 \mathrm{~m}$ and, secondarily, varying between 100 and $200 \mathrm{~m}$. Santo Antônio River Basin (directly related to the scarps of the Serra do Mar) presents relative relief generally above $300 \mathrm{~m}$, and secondarily between $200-300 \mathrm{~m}$ on slopes closer to the coastal plain.
The Land Use and Land Cover Types (Table IV) was considered as densely vegetated, due to the predominance of preserved Atlantic Forest. The urban area of Caraguatatuba is located near the slopes, mostly on the Coastal Plains, occurring few urbanization on the slopes themselves. Thus, we chose to use only one item (densely vegetated) for this parameter.

Hydrogeological condition (Table IV) was the parameter of greatest interpretative difficulty. Cliffs and slopes, due to declivity, rarely accumulate water and have a relatively deep water level. Thus, this parameter was characterized in the "damp" category, since it is not totally dry and this factor cannot be ignored. This region, due to the high annual rainfall index, usually above $1700 \mathrm{~mm}$, the average annual rainfall was considered greater than $150 \mathrm{~cm}$ annually (Table IV). It is known that precipitations are triggered agents of landslides and flows, so this parameter presented the highest possible rating value for the method.

Figure 4 shows the landslides hazard zonation for planar and wedge landslides for the northern portion of the Caraguatatuba, comprising the

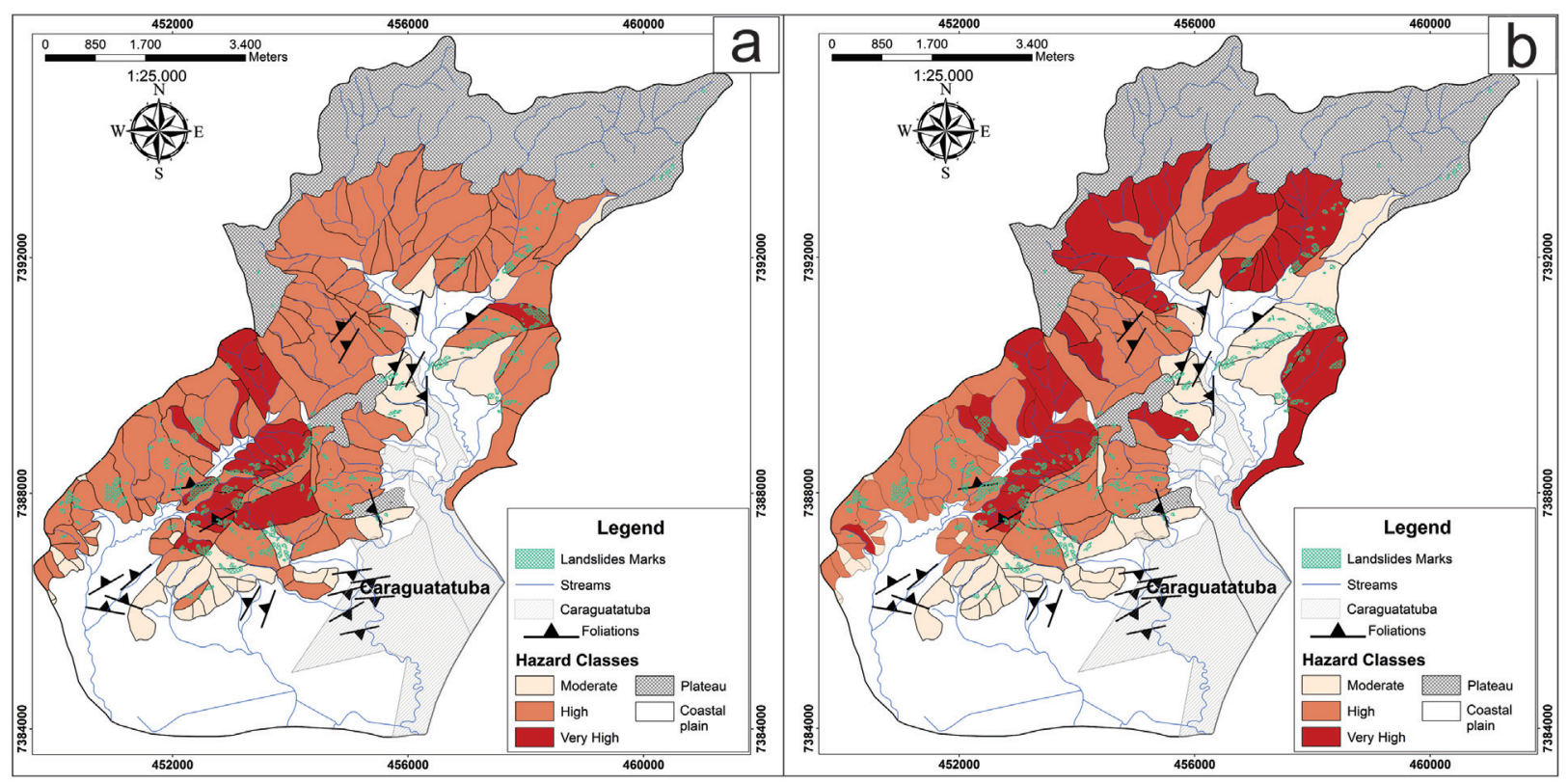

Figure 4 - Landslide Zonation Hazard map for the northeastern region of Caraguatatuba: (a) Planar Landslides and (b) Wedge Landslides. 
Canivetal and Rio Santo Antônio River Basins. In this region, excepting the regions of plateau and plains, hazards are mostrly characterized as high and sometimes very high. For planar landslides, there is a predominance of high hazard classes, and in some regions of the Canivetal River Basin, where slopes have NE-SE direction, with NW and $\mathrm{SE}$ inclination direction, there is an increase of susceptibility. This can be explained by the fact that these slopes present the same direction as the geological structures (foliation and bedding planes), increasing the grade attributed to this item, and potentiating the landslide occurrence. The hazard corresponding to wedge landslides shows an increase in the susceptibly degree, where more slopes fit in the very high hazard class. This type of landslide is related to the intersection between penetrative planar structures, that is, the intersection between foliations, fractures or both, generating a wedge where it can develop into a landslide.

\section{DISCUSSION}

As the general literature considers landslides of Serra do Mar as being translational / planar, an analysis of landslides and their relations with geological structures gains great relevance. Figure 5 shows the landslide zonation hazard of planar landslides, the geological structures and the landslides locations mapped. In full lines, slopes with NW and W inclination directions can be observed, agreeing with the main direction of the foliations in Canivetal River Basin. Dashed lines show local variation of foliation, with SE and $\mathrm{E}$ inclination direction and with NE-SW main

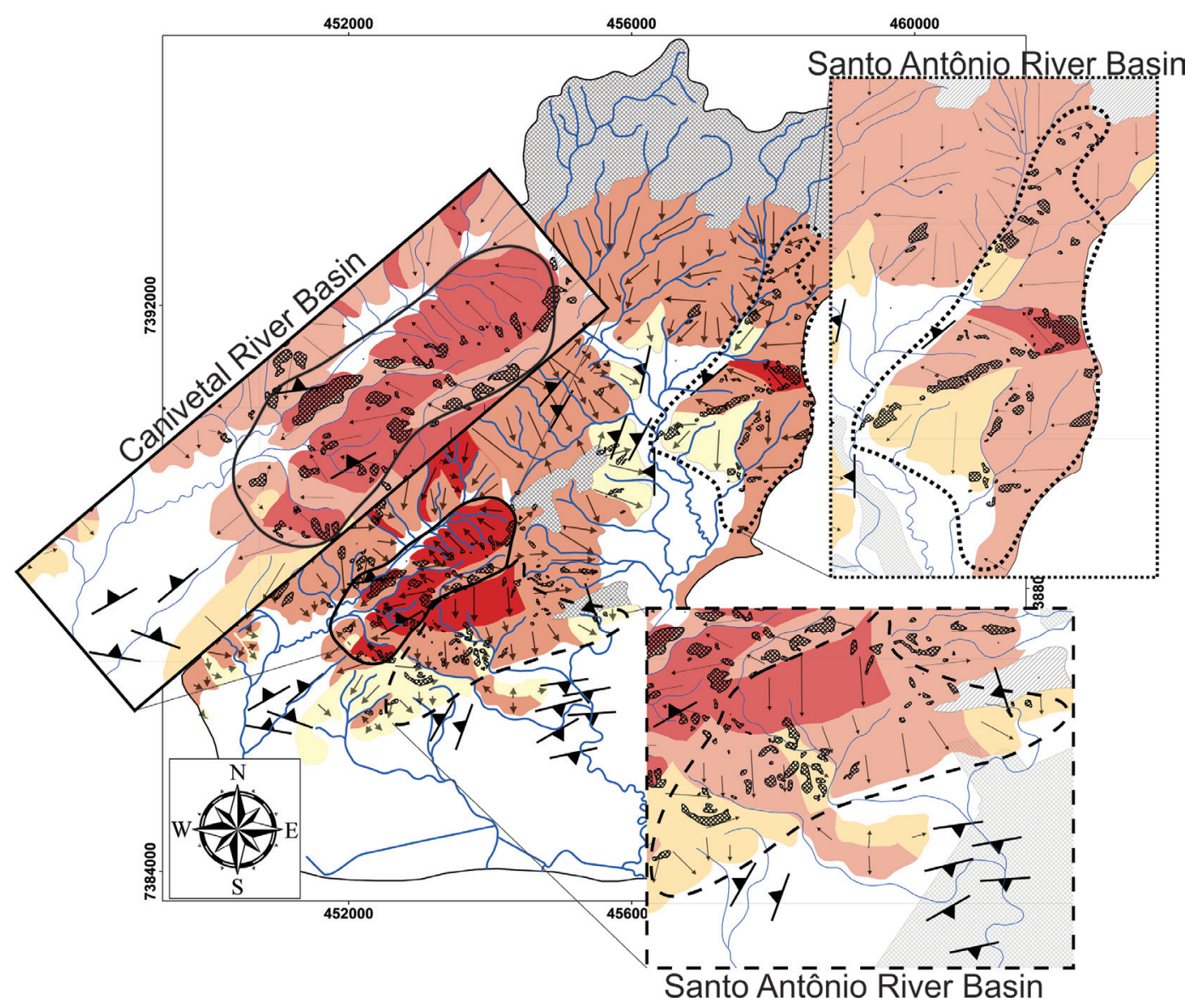

Figure 5 - Detail of the regions where there is clear structural control in the development of planar landslides. 
direction, conditioning landslides on slopes with the same inclination direction. In dotted lines, is observed a region of Santo Antônio River Basin, where landslides developed preferentially on slopes with inclination direction concordant with foliation.

For Canivetal River Basin, a great relation between landslides and geological structures is observed. There is a greater occurrence of landslides in the high and very high hazard classes. The eastern slopes (left margin of the Canivetal River) are predominantly individualized as very high hazard. These slopes presents dip value that agrees with the dip angle of the foliations $\left(26\right.$ to $\left.45^{\circ}\right)$. The western slopes (right margin of Canivetal River) are predominantly classified by high hazard, and the portions that have very high hazard are closely linked with the increase of declivity (approximately $\left.36-45^{\circ}\right)$. In this case, it is possible to verify the importance of the geological structures, both in fresh rocks and weathered rocks with preservation of geological structures (isalterites). The east portion, where foliations and slopes exhibit similar dip angle and dip directions, behave in a way to increase the degree of hazard (very high). On the other hand, the west portion, very high hazard classes are restricted to the places where declivities are higher. Thus, the number of landslides locations is greater in the portions where there is parallelism between geological structures and inclination of the slopes, with similar dip values. Areas of high hazard, located on the right margin of Canivetal river, are associated to an increase in declivity and relative relief, increasing the final hazard score, not being controlled by the structures, the opposite of what is observed in the left margin (east).

The final result of the landslides zonation hazard for Santo Antônio River Basin had satisfactory results in the relationship between landslides, hazard classes and geological conditions. This river basin presented, in its great majority, high hazard, with some slopes being classified as moderate and very high hazard. Most of the landslide locations are located in the high hazard class and generally on slopes with NW and W inclination direction, the same observed for foliations. In this way, landslides locations are located on slopes inclined to NW and W and sometimes SW / W, as can be seen in Figure 5 (shown in the dotted lines). It is also noted that in the south/east portion of this river basin, where there is predominance of slopes with NW and W inclination direction (indicated in Figure 5 in dotted lines), the landslides locations are more concentrated and have larger dimensions. In this way, it is verified that the slopes with the same inclination direction as the foliations, tend to present greater susceptibility to landslides.

Another factor of extreme importance for the occurrence of planar landslides related to foliations or other penetrative planar discontinuities is the relationship between structure and slope inclination . When slope inclination is greater than the dip angle value of geological structures, the possibility of occurrence of landslides increases (as can be seen in Table II). For planar and wedge landslides, high and very high hazard classes always have slope inclination greater than the dip angle value of foliations and fractures.

The association between landslide occurrence and geological structures becomes clearer when we observe the relation between the amount of landslides locations as a function of the slope inclination direction (Figures 6). The landslides locations in Canivetal and the Santo Antônio River Basins are concentrated in slopes mainly with NW, SW and W inclination direction. Slopes with the same dip direction of foliations (dipping to NW, $\mathrm{SE}$ and sometimes to $\mathrm{W}$ ) has a greater number of landslides locations if compared to other inclination directions. 
Slope Dip Direction vs. Number of Landslides Marks

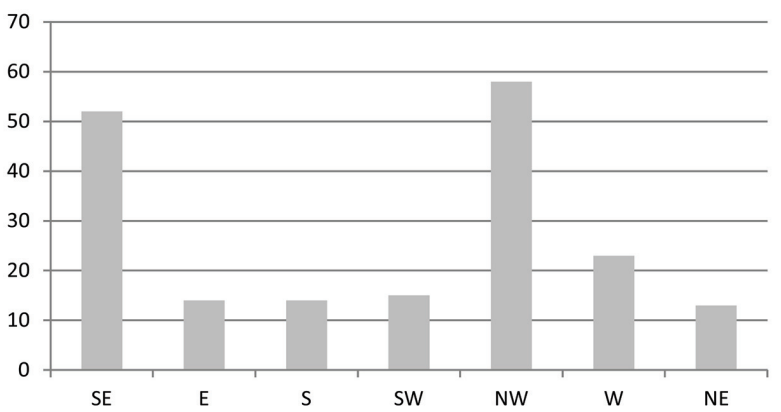

Figure 6 - Graph showing the relation between quantity of landslides locations and slope inclination direction.

\section{CONCLUSIONS}

The landslide zonation hazard proved to be an effective tool for slope analysis when comparing hazard zones to landslide locations. When planar landslides are analyzed, areas with high and/or very high hazard usually correspond to slopes that show landslides locations, validating the hazard zonation. It is observed that, for planar landslide analysis, the landslides locations, occur predominantly in high and very high hazard classes. The same landslides locations, when analyzed for the wedge landslide zoning, show a very high to moderate distribution, indicanting a strong relationship between planar landslides and penetrative planar geological structures.

The major advance of this study is to show the relationship between landslides locations and landslides events with planar and penetrative geological structures (foliations, joints, bandings, etc.) and their preservation in weathered profiles of tropical residual soils in the studied area. However, it is not possible to discard the possibilities of occurrence of wedge landslides in these regions, as can be observed in the obtained results. A joint analysis is the best option for a better view of zones/slopes where there is greater probability of landslides occurrence, both planar and wedge.

Thus, the relationship between landslides and the presence of geological structures preserved in isalterites and/or weathered rocks is valid when analyzing the amount of landslides as a function of the inclination direction of the slopes. This is validated when the slopes that present dip direction parallel or sub-parallel to the dip direction of the structures present the largest amounts of landslides locations. This clear and objective relationship is not observed when the number of landslides locations is analyzed as a function of the declivity, presenting a great heterogeneity and dispersion.

\section{ACKNOWLEDGMENTS}

The authors would like to thank the Brazilian research agencies, Coordenação de Aperfeiçoamento de Pessoal de Nível Superior (CAPES) and Conselho Nacional de Desenvolvimento Científico e Tecnológico (CNPq). The authors would also like to thank the Laboratório de Geologia de Engenharia e Meio Ambiente (GEMA) for technical and scientific support.

\section{REFERENCES}

ALMEIDA FF. 1964. Fundamentos Geológicos do Relevo Paulista. Boletim do Instituto Geográfico e Geológico.

ANBALAGAN R. 1992. Terrain Evaluation and Landslide Hazard Zonation for Environmental Regeneration and Land Use Planning in Mountainous Terrain. Proceedings of the sixth International Symposium on Landslides, Christchurch, p. 861-871

ANBALAGAN R, CHAKRABORTY D AND KOHLI A. 2008. Landslide hazard zonation (LHZ) mapping on mesoscale for systematic town planning in mountainous terrain. Journal of Scientific and Industrial Research 67: 486-497.

CAMPANHA GA, ENS HH AND PONÇANO EW. 1994. Análise morfotectônica do Planalto do Juqueriquerê, São Sebastião (SP). Braz J Geol, p. 32-42.

CARVALHO CM AND RIEDEL PS. 2005. Técnicas de Geoprocessamento aplicadas ao estudo de susceptibilidade a escorregamentos translacionais nos entornos dos Polidutos de Cubatão - SP. Anais do XII Simpósio Brasileiro de Sensoriameneto Remoto, Goiânia, p. 2901-2908.

CERRI LE AND ALMEIDA JG. 1990. Instabilidade da Serra do Mar no Estado de São Paulo: situações de risco. Anais do I Simpósio Latino-Americano sobre Risco Geológico Urbano. São Paulo (SP): ABGE São Paulo, p. 342-351. 
CHIEREGATILA, THEODOROVICZAM, THEODOROVICZ A, MENEZES RG, CHIODI FILHO C AND RAMALHO R. 1982. Projeto Folhas Natividade da Serra e Caraguatatuba: Relatório Final. São Paulo: Companhia de Pesquisa de Recursos Minerais, Diretoria da Área de Pesquisas, Superintendência Regional de São Paulo.

COWLAND JW AND CARBRAY AM. 1988. Three cut slope failures on relict discontinuities in saprolitic soils. II International Conference on Geomechanics in Tropical Soils, Singapura, p. 253-258.

CRUZ O. 1974. A Serra do Mar e o litoral na área de Caraguatatuba - SP - contribuição à geomorfologia litorânea tropical. Tese de Doutorado, Geografia, Universidade de São Paulo, p. 181.

CRUZ O. 1975. Evolução de vertentes nas escarpas da Serra do Mar em Caraguatatuba, São Paulo. An Acad Bras Cienc 47(Supl): 479-480.

DNPM/CPRM. 1991. Mapa Geológico da Folha Pico do Papagaio 1:50000. Projeto de Integração Geológica da Região Metropolitana de São Paulo.

FONSECA AP, LACERDA WA, FUTAI MM AND AGUIAR VN. 2005. Influência do teor de mica na resistência ao cisalhamento residual em taludes de solos saproléticos de gnaisse. IV COBRAE, Salvador, p. 205-212.

GOBBI F, BERNARDES JA, BICA AV, BRESSANI LA, FLORES JA AND AZAMBUJA E. 2005. Estudo da resistência ao cisalhamento do solo residual de gnaisse Porto Alegre. IV COBRAE, Salvador, p. 173-181.

GRAMANI MF. 2001. Caracterização geológica-geotécnica das corridas de detritos ("Debris Flows") no Brasil e comparação com alguns casos internacionais. Dissertação de Mestrado (Mestrado em Engenharia de Solos). Escola Politécnica, Universidade de São Paulo, São Paulo, p. 372. (Unpublished).

HASUI Y, CARNEIRO CD, ALMEIDA FF AND BARTORELLI A. 2012. Geologia do Brasil. São Paulo: Oficina de Textos.

HASUI Y ET AL. 1978. Geologia da região administrativa 3 (Vale do Paraíba) e parte da Região Administrativa 2 (Litoral) do estado de São Paulo: Mapa Geológico em escala 1:200.000. Instituto de Pesquisas Tecnológicas (IPT. Monografias, 1), Publicação IPT n. 1106. (Unpublished).

HEILBRON M ET AL. 2004. Província Mantiqueira. In: Mantesso-Neto V, Bartorelli A, Carneiro CD and BritoNeves BB. Geologia do continente sul-americano: evolução da obra de Fernando Flávio Marques de Almeida. Beca São Paulo, p. 203-235.

IPT - INSTITUTO DE PESQUISAS TECNOLÓGICAS. 1987. Estudos das instabilizações da Serra do Mar na Região de Cubatão, objetivando a caracterização do fenômeno «corrida de lama» e a prevenção de seus efeitos. São Paulo: Relatório IPT no. 25065.

IPT - IINSTITUTO DE PESQUISAS TECNOLÓGICAS. 1988. Estudos da instabilização de encostas da Serra do
Mar na Região de Cubatão, objetivando a caracterização do fenômeno "corrida de lama" e a prevenção de seus efeitos. São Paulo: Relatório IPT no. 25258.

IPT - IINSTITUTO DE PESQUISAS TECNOLÓGICAS. 1991. Desenvolvimento de um plano de estudos para análise, prevenção e contenção do fenômeno da corrida de massa na Região de Cubatão, em colaboração com o Governo Japonês. São Paulo: Relatório IPT no. 29123.

IPT - IINSTITUTO DE PESQUISAS TECNOLÓGICAS. 2000. Diagnóstico da situação atual dos recursos hídricos da Unidade de Gerenciamento dos Recursos Hídricos do Litoral Norte: relatório final. São Paulo: Relatório no. 46172.

IRFAN TY AND WOODS NW. 1988. The influence of relict discontinuities on slope stability in saprolitic soils. International Conference on Geomechanics in Tropical Soils, Singapura, p. 267-276.

LOPES ES, RIEDEL PS, BENTZ CM, FERREIRA MV AND NALETO JL. 2007. Inventário de escorregamentos naturais em banco de dados geográficos - análise dos fatores condicionates na região da Serra de Cubatão SP. XIII Simpósio Brasileiro de Sensoriamento Remoto, Florianópolis, p. 2785-2796.

MACHADO FILHO JG. 2000. Estabilidade de encostas e condicionantes geológicos, geomorfológicos e estruturais, num trecho da Serra de Cubatâo. Dissertação de Mestrado, Universidade de São Paulo, p. 172. (Unpublished).

MARCELINO EV. 2003. Mapeamento de áreas susceptíveis a escorregamento no município de Caraguatatuba (SP), usando técnicas de sensoriamento remoto. Dissertação de Mestrado. São José dos Campos, Instituto Nacional de Pesquisas Espaciais (INPE), p. 228. (Unpublished).

MODENESI MC AND TOLEDO MC. 1993. Morfogênese quaternária e intemperismo: Colúvios do planalto de Itatiaia. Rev Inst Geol de São Paulo, p. 45-53.

MOURA CA, MATTOS JT AND JIMÉZES-RUEDA JR. 2012. Análise de fraturamentos para determinação de áreas instáveis na faixa de dutos Osvat/Osplan - São Sebastião, em São Paulo. Rev Bras Geociênc 42(3): 585-596.

NAKAZAWA VAAND CERRI LE. 1990. Os escorregamentos ocorridos em Petrópolis - RJ em fevereiro de 1988: ações emergenciais. Anais do I Simpósio Latino-Americano sobre Risco Geológico Urbano. São Paulo: ABGE São Paulo, p. 325-333.

OGURA AT AND AUGUSTO FILHO O. 1991. The Morin Debris-Flow Disaster at Petropolis City, Rio de Janeiro State, Brazil. Landslides News, p. 22-25.

PAITAN CA, JUNIOR EA AND VELLOSO RQ. 2014. Um Estudo Numérico da Influencia de Fraturas nos Padrões de Fluxo em Encostas. XVII Congresso Brasileiro de Mecânica dos Solos e Engenharia Geotécnica. Goiânia, GO.

PONÇANO WL. 1981. Mapa Geomorfológico do Estado de São Paulo. Instituto de Pesquisas Tecnológicas do Estado de São Paulo, Divisão de Minas e Geologia Aplicada. 
RAMOS VM, GUIMARÃES RF, REDIVO AL, GOMES RA, FERNANDES NF AND CARVALHO JÚNIOR OA. 2002. Aplicação do modelo SHALSTAB em ambiente ArcView, para o mapeamento de áreas susceptíveis a escorregamento raso na Região do Quadrilátero Ferrífero (MG). Espaç Geogr, p. 49-67.

ROSS JL AND MOROZ IC. 1997. Mapa Geomorfológico do Estado de São Paulo. Departamento de Geografia (FFLCH - USP). Laboratório de Cartografia Geotécnica - Geologia Aplicada - IPT/FAPESP.

SILVA DR. 2013a. Avaliação da contribuição de sistemas de fraturas nas condições de fluxo e estabilidade de encostas.
Dissertação de Mestrado, Universidade Estadual do Paraná, p. 92. (Unpublished).

SILVA RF. 2013b. Análise de magnitude e frequência espacial de movimentos de massa em Caraguatatuba-SP. Tese de Doutorado, Universidade de São Paulo, São Paulo, p. 96.

SOUZA NETO JB, LACERDA WA AND COUTINHO RQ. 2001. Variabilidade nos parâmetros geotécnicos de alguns solos residuais brasileiros. III COBRAE, Rio de Janeiro, p. 305-315.

VIEIRA BC AND GRAMANI MF. 2015. Serra do Mar: The Most "Tormented" Relief in Brazil. In: Vieira BC, Salgado AA and Santos LJ. Landscapes and Landforms of Brazil, Springer, p. 285-297. 